井上 貴之, 村上 順一, 佐野 史歩

林 雅太郎, 上田 和弘, 濱野 公一

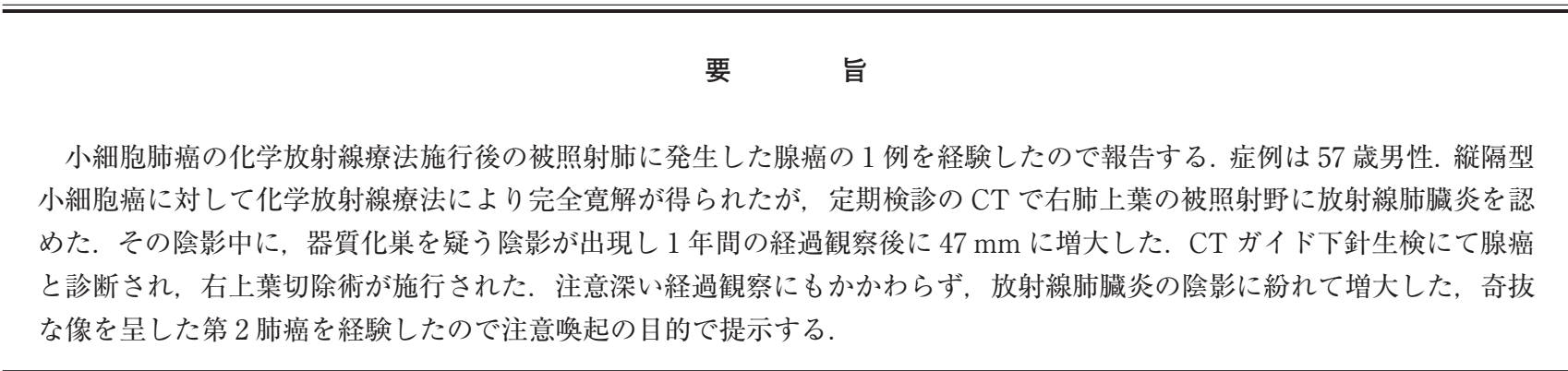

索引用語 : 小細胞肺癌, 化学放射線療法, 第 2 癌

small cell lung cancer, chemoradiotherapy, metachronous lung cancer

はじめに

小細胞肺癌は化学療法と放射線療法の同時併用など集 学的治療により 3 年生存率 $30 \%$ と予後の改善が示され ており, 長期生存例が増えてきている ${ }^{1}$. また小細胞肺癌 治療後に第 2 肺癌が発生する相対危険度は同世代と比較 して高いとされ2), そのため, 小細胞肺癌治療後に第 2 肺癌が発生する頻度が増加することが予想される．第 2 肺癌の治療には積極的に外科治療を行った報告も散見さ れるが, 小細胞肺癌治療時に放射線照射をすでにされて おり, 外科治療より化学療法が施行されることの方が多 い. その理由として, 放射線照射の影響により第 2 肺癌 の発見が遅れ進行癌として発見されることと第 2 肺癌を 早期に診断しても, 呼吸機能低下により切除不能と診断 されるためと考えられる ${ }^{3)}$. 今回, 小細胞肺癌の化学放射 線療法施行後の被照射肺に発生した腺癌の 1 切除例を経 験したので文献的考察を加えて報告する。

山口大学大学院医学系研究科器官病態外科学

原稿受付 2016年 1 月19日

原稿採択２016年 2 月 12 日

\section{症例}

症 例 : 57 歳 男性.

主 訴: 検診での異常.

現病歴 : 検診の胸部レントゲン写真で異常を指摘さ れ, 精查の結果, 気管前リンパ節の腫大を指摘された。 縦隔鏡生検にて縦隔限局型小細胞肺癌と診断された. 化 学放射線療法 (CDDP : $80 \mathrm{mg} / \mathrm{m}^{2}+\mathrm{VP}-16: 100 \mathrm{mg} / \mathrm{m}^{2}$ 6 コース, $36 \mathrm{~Gy} / 12$ 回), 予防的全脳照射 ( $2.5 \mathrm{~Gy} / 10 \mathrm{fr} /$ $25 \mathrm{~Gy})$ を施行され, Complete Response (CR) となった. $\mathrm{CR}$ となった 8 カ月後の胸部 CT で右肺上葉の放射線照 射部位に放射線肺臓炎を認めた。肺臓炎の陰影に重なり 肺囊胞を認めていたが, 経過観察にて囊胞壁が肥厚し, 徐々に囊胞内を占拠するように増大した，CR となった 22 力月後にCT ガイド下生検が施行され腺癌と診断さ れた。

既往歴： 55 歳，横行結腸癌 (pT1N0M0, stage I) で手 術.

喫煙歴 : 20 本/日, 37 年間, 小細胞癌診断後より禁煙.

入院時現症：特記事項なし.

血液検查所見 : CA19-9 : 104.7 U/ml, SLX : $47 \mathrm{U} / \mathrm{ml}$ と上昇を認めたが, その他の腫瘍マーカーは正常範囲内 


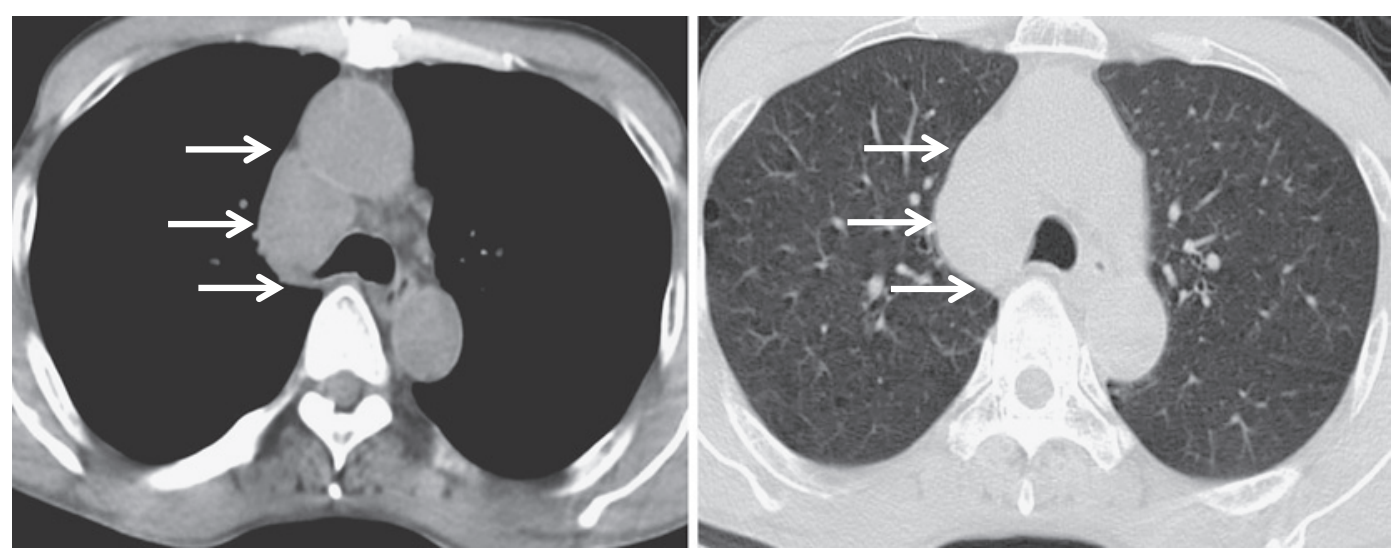

Fig. 1 Chest computed tomography of limited disease small cell lung cancer before chemoradiotherapy showing a well-defined mass, of $38 \mathrm{~mm}$ in diameter within the upper mediastinum.
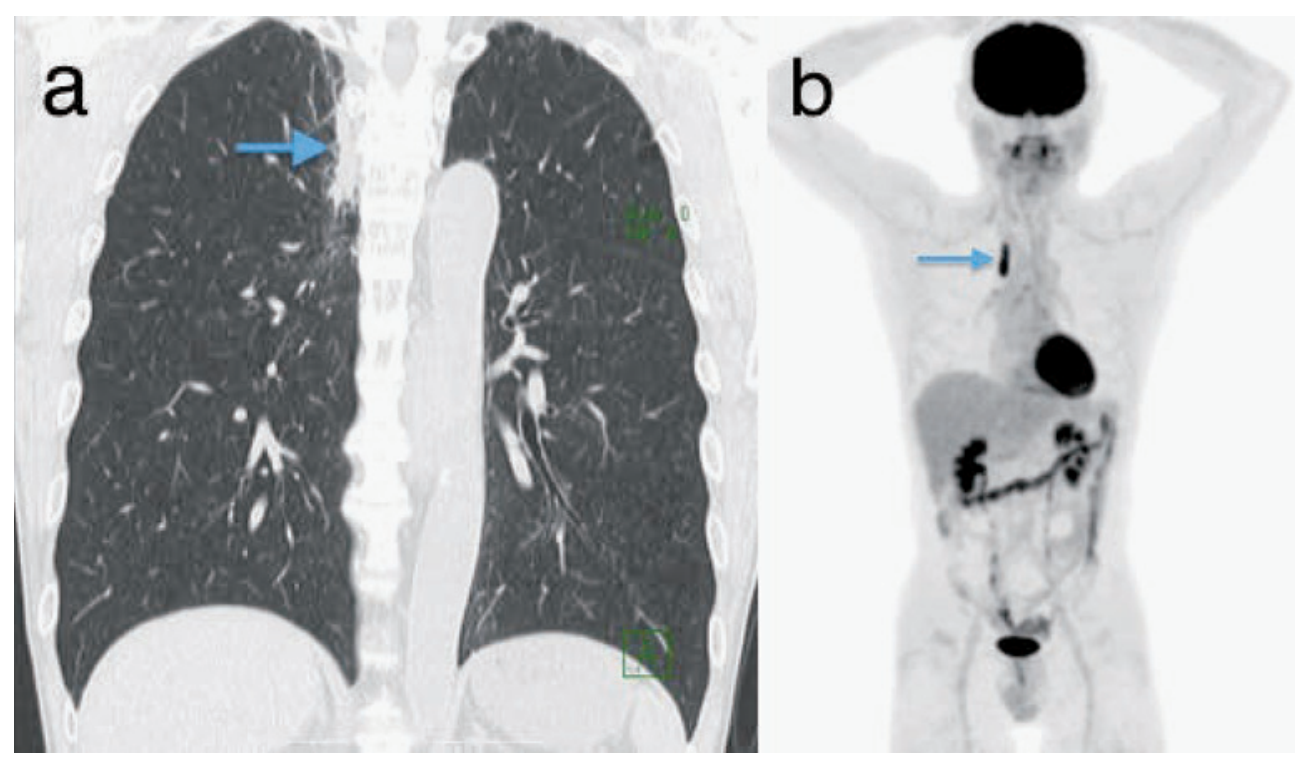

Fig. 2 Preoperative chest computed tomography showing the slender mass in the right upper lobe (a), accompanied by significant accumulation (maximum standardized uptake value of 9.2) on positron emission tomography (b).

であった，血液生化学検查に異常所見を認めなかった。

肺機能検査所見：FVC $3.58 \mathrm{~L} ％$ VC 103.5\%， FEV 1.0 $2.96 \mathrm{~L}, \mathrm{FEV}_{1.0 \%} 82.68 \%$, \%DLCO 71.6\%.

胸部 CT : 化学放射線療法前 : 中縦隔に境界明膫な 38 $\mathrm{mm}$ 大の腫瘤を認めた. 肺門, 縦隔にリンパ節腫大は認め なかった (Fig. 1).

手術前 : 放射線照射部位の右肺上葉に頭尾側方向に径 $47 \mathrm{~mm}$ の細長い索状陰影を認めた. 周囲には気腫性変化 や線維化を認めた (Fig. 2). 院影は上下葉間の不全分葉を 介して S6 まで連続していた。
FDG-PET : 索状腫瘤影に一致して, SUVmax : 9.2 の FDG 集積を認めた. その他に肺門縦隔リンパ節転移, 遠隔転移を認めなかった（Fig. 1).

CT ガイド下生検 : Adenocarcinoma, TTF-1 (-), SP$\mathrm{A}(-), \operatorname{CK} 7(+), \mathrm{CK} 20(+), \operatorname{CDX} 2(-)$ 既往の大 腸癌とは免疫染色パターンが異なり, 肺原発と考えられ た。

手術所見 : 3 ポートからの胸腔鏡下に手術を行った. 胸水, 胸膜播種は認めなかった. 放射線照射のため, 肺 門, 縦隔の組織は硬化していた。 上下葉間の不全分葉を 


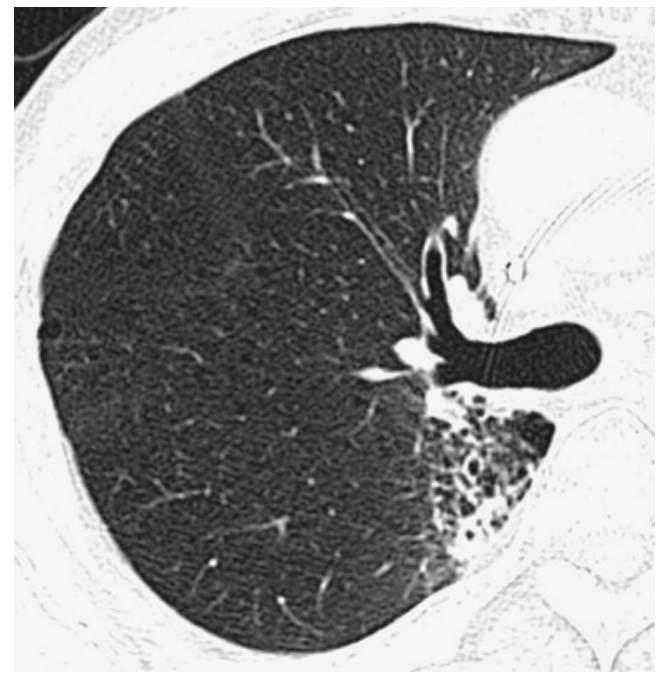

Fig. 3 Chest computed tomography taken 8 months after chemoradiotherapy showing radiation pneumonitis with cystic formation in the right upper lobe.

介して, 腫瘍は S6 に進展していたため, 右肺上葉と S6 を一塊に切除し、リンパ節郭清（ND2a-2）を行った。

病理所見: 腫瘍は $43 \times 10 \mathrm{~mm}$, Invasive adenocarcinoma, papillary predominant, G2, Ly0, V0, pl0, br $(-)$, EGFR mutation $(-)$, ALK fusion gene $(-)$, pT2aN0M0, stage IB と診断した. 上縦隔リンパ節に小細 胞癌の遺残を認めなかった。

術後経過：術後合併症なく, 術後 10 日目に退院した。 現在, 術後補助化学療法 (UFT $400 \mathrm{mg} /$ day) を施行して いる。

\section{考察}

2 次癌とは先行する癌に対する化学療法や放射線療法 などの治療が要因となって癌が続発することをいうが, 個々の症例で 2 次癌または第 2 癌（第 1 癌との関連は問 わずに第 2 番目の癌が発生すること）を特定することは 困難な場合が多い4).

小細胞肺癌治療後の 2 次癌発生の相対危険度は高いと される。その発生率は同世代と比較して, 全臟器におけ る癌発生で 3.5 倍, 喫煙関連の癌では 7 倍, 肺癌では 7 16 倍, 軟部腫瘍で 22 倍, 急性非リンパ性白血病で 25 倍とされている2．また第 2 癌（または 2 次癌）発生の原 因として契煙と化学療法や放射線療法などの治療関連因 子が挙げられる ${ }^{4)}$. Tucker らは小細胞肺癌の治療後, 2
年以上生存した 611 例を対象とし，第 2 癌のリスク因子 について検討している，第 2 癌が肺癌の場合，健康人口 に比べて発癌リスクが放射線治療併用群で 13 倍, 非併用 群で 7 倍であり，さらに放射線治療併用群が喫煙を継続 した場合は 21 倍であったと報告している5 . また Travis らがホジキンリンパ腫に対する化学療法, 放射線療法後 の肺癌発生のリスク因子について検討している。 $40 \mathrm{~Gy}$ 以上の dose での放射線療法，アルキル化薬を用いた化 学療法, 喫煙歴ありの 3 点が肺癌発生のリスク因子であ るが，特に現在も契煙歴のあるものはハイリスク因子で あると報告している ${ }^{6}$. 本症例は既契煙者で初回治療前に 禁煙されたが，小細胞癌に対して化学放射線療法を行っ ており，第 2 癌の発生リスクが高かったと思われる.

酒井らが放射線誘発癌についての確信度分類を報告し ている. 第 1 癌と第 2 癌の組織型及び発生臟器が異なり, かつ第 1 癌より 5 年以上の潜伏期間を有し，放射線照射 部位に発生した癌は放射線誘発癌の確信度が高いとして いる．上記 3 つの診断条件がそれぞれ否定されれば，放 射線誘発癌の可能性は段階的に低くなると報告してい $る^{7}$. 本症例では第 2 癌は放射線照射部位に一致して, 第 1 癌と組織型の異なる癌が発生しているが，発生藏器は 同一で潜伏期間が 8 力月と短く, 放射線誘発癌の確信度 は低く, 放射線療法による 2 次癌の可能性は少ないと考 えている. しかし，小細胞肺癌の剖検症例ではその 13$28 \%$ に非小細胞癌組織の混在があったと報告されてい る $^{8-10)}$ ．本症例では小細胞肺癌に対する初回治療前の CT で, 今回の肺腺癌の陰影を指摘することは出来なかった. 加えて縦隔鏡下生検で採取した $1 \mathrm{~cm}$ 大の組織片を再検 したものの, 全て小細胞癌から構成されており, 腺癌成 分は認めなかった。

小細胞肺癌治療後の長期生存者の $80 \%$ は限局型であ り，放射線療法が施行されていることが多い．放射線療 法の合併症として放射線肺臟炎が発生する頻度は 0-49\% と報告されており，放射線照射量 $40 \mathrm{~Gy}$ 以上で高率に発 生するとされている ${ }^{11)}$. 本症例では縦隔型小細胞肺癌に 対する縦隔への照射に伴い右上葉の一部が照射野に入 り，同部に放射線肺臟炎を認めた (Fig. 3)。さらに既存の 肺囊胞壁が徐々に肥厚する経時的な陰影の変化 (Fig. 4), 頭尾側方向に細長く分布する索状影 (Fig. 2) は器質化肺 炎を疑わせるものであり，必ずしも癌を積極的に疑う所 見ではなかった. 特に $43 \times 10 \mathrm{~mm}$ という長細い腫瘍の形 態は奇抜であり，陰影の出現から癌の診断までに 1 年余 


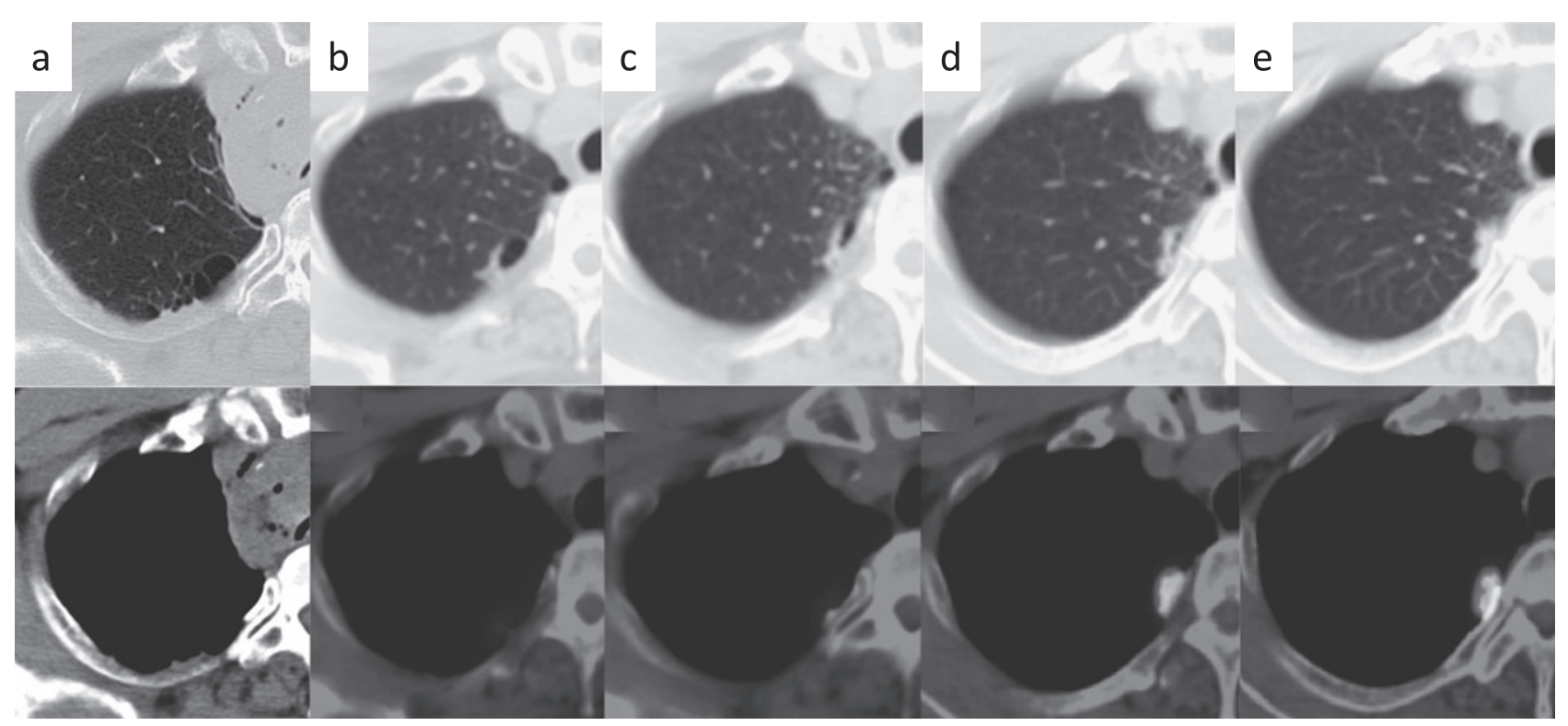

Fig. 4 Periodical chest positron emission tomography/computed tomography taken before chemoradiotherapy (a), and at 8 months (b), 14 months (c), 20 months (d), and 24 months (e) after chemoradiotherapy, showing a successive increase in the nodular size and accumulation.

を要した要因である. 本邦での小細胞肺癌に対する放射 線療法後の第 2 肺癌の発生について, 医中誌 WEB で以 下の key word [放射線, 肺癌, 第 2 癌, 2 次癌] で検索 を行った，検索し得たもので，小細胞肺癌の放射線療法 後に第 2 肺癌が発生した症例は 16 例あり, 第 2 癌が放射 線照射野に発生した症例は 4 例であった。実際に，第 2 癌の陰影が放射線肺臓炎と混同されることで精査や加療 が遅れてしまい, 病期が進行した状態で発見された事例 が報告されている ${ }^{12.13)}$. 前述のように本症の腺癌は 2 次癌 ではないものの, その進展に放射線被爆が影響した可能 性はあるが, 被照射肺と癌進展の関連に言及した報告は 今のところ見当たらない.

\section{結語}

限局型小細胞肺癌に対し化学放射線療法施行後に CR となったが, 被照射肺に腺癌が発生した 1 例を経験した。 小細胞肺癌の治療成績向上に伴って第 2 肺癌に遭遇する 頻度は増すことから, その可能性を念頭に置いて定期検 診を行う必要がある.

\section{利益相反}

本論文について申告する利益相反はない.

\section{文献}

1. Takada M, Fukuoka M, Kawahara M, Sugiura T, Yokoyama A, Yokota S, et al. Phase III study of concurrent versus sequential thoracic radiotherapy in combination with cisplatin and etoposide for limited-stage small-cell lung cancer: results of the Japan Clinical Oncology Group Study 9104. J Clin Oncol 2002; 20: 3054-60.

2. 桃實 徹, 東山聖彦, 前田 純, 岡見次郎, 尾田一之, 今 村文生, 他. 肺小細胞癌化学療法後に発生した異時性多発 肺癌の外科治療. 胸部外科 2009; 62: 117-21.

3. Johnson BE. Second lung cancers in patients after treatment for an initial lung cancer. J Natl Cancer Inst 1998; 90: $1335-45$.

4. 小中千守. 小細胞肺癌における二次発癌と予防. 肺癌の臨 床 1998; 1: 309-13.

5. Tucker MA, Murray N, Shaw EG, Ettinger DS, Mabry $\mathrm{M}$, Huber MH, et al. Second primary cancers related to smoking and treatment of small-cell lung cancer. Lung Cancer Working Cadre. J Natl Cancer Inst 1997; 89: 1782 8.

6. Travis LB, Gospodarowicz M, Curtis RE, Clarke EA, Andersson M, Glimelius B, et al. Lung cancer following che- 
motherapy and radiotherapy for Hodgkin's disease. J Natl Cancer Inst 2002; 94: 182-92.

7. 酒井邦夫, 日向 浩, 北村達夫. 放射線治療と発癌. 臨床 放射線 1981; 26: 865-9.

8. Sehested M, Hirsch FR, Osterlind K, Olsen JE. Morphologic variations of small cell lung cancer. A histopathologic study of pretreatment and posttreatment specimens in 104 patients. Cancer 1986; 57: 804-7.

9. Abeloff MD, Eggleston JC, Mendelsohn G, Ettinger DS, Baylin SB. Changes in morphologic and biochemical characteristics of small cell carcinoma of the lung. A clinicopathologic study. Am J Med 1979; 66: 757-64.
10. Brereton HD, Mathews MM, Costa J, Kent CH, Johnson RE. Mixed anaplastic small-cell and squamous-cell carcinoma of the lung. Ann Intern Med 1978; 88: 805-6.

11. 畑山佳臣, 青木昌彦, 近藤英宏, 川口英夫, 阿部由直. 放 射線肺臓炎の発症予測に関する平均肺線量計測の有用 性. 肺癌 2007; 47: 695-700.

12. 丸山真博, 塩野知志, 加藤博久, 佐藤 徹, 柳川直樹. 小 細胞肺癌完全寛解後に発生した異時性多発肺癌の 1 例.

胸部外科 2006; 59: 164-7.

13. 涉佐 隆, 大沼菊夫, 樋口光徳, 美佐健一. 小細胞肺癌術 後 15 年目に合併した肺扁平上皮癌の 1 例. 肺癌 2010; 50: $166-71$.

\title{
A case of secondary lung cancer developing after chemoradiotherapy for small cell lung cancer
}

\author{
Takayuki Inoue, Junichi Murakami, Fumiho Sano \\ Masataro Hayashi, Kazuhiro Ueda, Kimikazu Hamano \\ Department of Surgery and Clinical Science, Division of Chest Surgery, \\ Yamaguchi University Graduate School of Medicine, Yamaguchi, Japan
}

We report a 57-year-old man with secondary lung cancer developing after chemoradiotherapy for small cell lung cancer. The patient developed radiation pneumonitis after having achieved the complete remission of small cell lung cancer. The radiation pneumonitis diagnosed on computed tomography appeared to progress into a nodular lesion which resembled focal fibrosis. Because of a successive increase in size, the nodule was eventually diagnosed as lung adenocarcinoma by percutaneous needle biopsy. The patient underwent complete resection without any significant perioperative complications. We describe this instructive case in order to stress the importance of not delaying the timing of diagnosis and treatment of such an eccentric nodule arising within radiation pneumonitis. 